\title{
Hubungan Raja dengan Rakyat dalam Kohesi Sosial Melayu Islam
}

\author{
Wan Zailan Kamaruddin Wan Ali \\ (Akademi Pengajian Islam Universiti Malaya, Kuala Lumpur, Malaysia; wək_ali@um.edu.my)
}

\begin{abstract}
In the context of the Malay world, Islam and the Malays are not inseparable. Islam is the "agama", "a way of life," "system and way of life" or more precisely, "al-Din" and Malay are also race and adherents. It seems that Islam is strong and strengthening the Malays, while Malays are strong and strengthened with Islam. In the context of Taj al-Salatin, the issue of leadership (alImamah wa al-Khilafah) or the issue of the rulers (al-Ra 'i wa al-Ra'iyyah) was seriously debated. Is it in parallel with the Qur'an and al-Hadith, and fulfilling the reference and the framework of Islamic political thought is interesting to study. Apparently, it also presents examples from nonIslamic sources that certainly invite controversy. Collected data is analyzed in a comparative basis based on qualitative methods. The main objective of this article will be on leadership issues, the rulership of the people (al-ra'i wa al-ra'iyyah) from the perspective of Islamic Political Thoughts with the results hoped to belp Islamic politics and Malay politics to go along and align to fulfill and realize Islam as "Din al-Hayat" and Malay as one of the ummah of "umam muslimah" who became bis supporters and supporters to achieve bis excellence and glory not only in the context of the Malay World and the Islamic World.
\end{abstract}

Keywords: social history; Malay society; the Malay kingship

\begin{abstract}
Abstrak
Dalam konteks Alam Melayu, Islam dan Melayu berpisah tiada. Islam merupakan "a-gama", "a way of life," "sistem dan cara hidup" atau lebih tepat, "al-Din" dan Melayu pula merupakan bangsa dan penganutnya. Kelihatan Islam kukuh dan mengukuhkan Melayu, manakala Melayu kukuh dan diperkukuhkan dengan Islam. Islam menjadi kuat dengan para penganutnya, manakala Melayu menjadi kuat dengan mengikuti Islam sebagai "a way of life." Dalam konteks kitab Taj al-Salatin, isu kepimpinan (al-Imamah wa al-Khilafah) atau isu raja-rakyat (al-Ra'i wa al-Ra'iyyah) dibahaskan secara serius. Adakah ia selari dengan al-Qur'an dan al-Hadith, dan memenuhi acuan dan kerangka pemikiran politik Islam adalah sesuatu yang menarik untuk dikaji. Kelihatan, ia turut mengemukakan contoh daripada sumber non-Islam yang pastinya mengundang kontroversi. Data-data yang terkumpul dianalisis secara perbandingan berasaskan metode kualitatif. Objektif utama artikel ini akan terarah kepada isu kepimpinan, hubungan raja-rakyat (al-ra'i wa al-ra'iyyah) dari perspektif Pemikiran Politik Islam dengan hasilnya diharap dapat membantu politik Islam dan politik Melayu berjalan seiring dan sejalan untuk memenuhi dan merealisasi Islam sebagai "Din al-Hayat" dan Melayu sebagai salah sebuah ummah daripada "umam
\end{abstract}


muslimah" yang menjadi pendokong dan penyokongnya mencapai kecemerlangan dan kegemilangannya bukan sahaja dalam konteks Alam Melayu bahkan Dunia Islam.

\section{Kata Kunci: sejarah sosial; masyarakat Melayu; kerajaan Melayu}

\section{A. Pendahuluan}

Setiap masyarakat punya resep kohesi sosial tertentu. Demikian karena kohesi social merupakan keadaan di mana anggota kelompok atau masyarakat bersatu padu sebagai hasil dari interaksi dan ikatan sosial tertentu. Dalam kohesi sosial tersebut, konsep otoritas selalu muncul manakala diperlukan adanya pihak yang menjalankan cita-cita bersama. Otoritas sendiri berbeda-beda bentuknya, ada otoritas tradisional, karismatik, dan ada otoritas rasional. ${ }^{1}$ Masyarakat Melayu sudah berzaman-zaman mempunyai kohesi sosial yang dipersatukan oleh raja. Ini salah satu bentuk otoritas tradisional yang ditetapkan oleh tradisi, adat istiadat, kepercayaan, dan diturunkan dari generasi ke generasi.

Konsep kepimpinan (raja-rakyat) merupakan suatu konsep Islam yang terpenting selepas konsep kenabian dan kerasulan, kerana ia lanjutan daripada institusi kenabian, berkaitrapat dengan persoalan pentadbiran dan pengurusan aspekaspek kemanusiaan, kenegaraan dan keagamaan, duniawi dan ukhrawi, selain ia juga sebagai lambang kekuasaan Islam.

Manusia sebagai makhluk sosial dikatakan memerlukan pemimpin dan kepimpinan kerana kehidupan bermasyarakat yang sempurna menghendaki keharmonian dan keadilan dalam tatacara kehidupan. Oleh itu, keharmonian dan keadilan tidak akan wujud tanpa kepemimpinan yang mempunyai sifat-sifat tertentu

\footnotetext{
${ }^{1}$ Rahman, M. Taufiq. Glosari Teori Sosial. Bandung: Ibnu Sina Press. 2011, h. 54 dan 84. 


\section{ARTIKEL}

E-ISSN: 2615-5028

yang berdasarkan ketetapan Allah s.w.t bagi menjamin institusi kepemimpinan itu sendiri.

Dari pandangan al-Qur'an, kepimpinan dianggap suatu kewajipan kerana tanpanya, segala ajaran, amalan Islam dan bahkan kebajikan masyarakat Islam itu sendiri tidak akan dan tidak mungkin dapat dilaksanakan dan dicapai matlamatnya. Kepimpinan itu pula diperlihatkan oleh Allah berhubung dengan manusia sematamata tetapi tidak pula dikaitkan dengan makhluk-makhluk Allah yang lain. ${ }^{2}$ Manusia dikatakan mempunyai tugas dan tanggungjawab yang berat untuk memimpin sesama mereka di dunia ini. Kenyataan tersebut menunjukkan bahawa hanya manusia sahaja yang wajar bertindak sebagai wakil Allah (s.w.t) untuk merealisasikan kehendak dan keredhaan Allah.

Oleh itu, institusi kepimpinan merupakan suatu tuntutan wajib untuk kemaslahatan manusia sejagat. Ini kerana menerusi institusi ini, semua bidang kehidupan manusia sama ada agama, politik, ekonomi, sosial dan sebagainya akan mendapat bimbingan, petunjuk dan pedoman daripada para pemimpin pilihan Allah sendiri yang pada akhirnya akan membawa sekalian manusia kepada matlamat akhirnya iaitu kesempurnaan dan kebahagiaan hidup di dunia dan lebih-lebih lagi di akhirat.

Dalam sejarah Islam, persoalan kepimpinan telah disepakati umum di kalangan ulama, cendikiawan, sejarawan dan juga pemikir sama ada muslim mahupun non-muslim sebagai persoalan kontroversi yang paling utama di kalangan umat Islam. ${ }^{3}$ Ia pada hakikatnya telah meninggalkan kesan dan implikasi yang begitu

2 Al-Qur'an, surah al-Baqarah (2): 30; al-A'raf (7): 129.

${ }^{3}$ Al-Syahrastani, al-Milal, I, h.22. 


\section{ARTIKEL}

E-ISSN: $2615-5028$

besar kepada Islam dan umat Islam itu sendiri sehingga mencetuskan pelbagai isu, problem dan perpecahan yang berlanjutan sehingga kini.

Justeru, artikel ini dikemukakan bertujuan untuk meneliti dan mengkaji kedudukan dan hubungan raja-rakyat (al-ra'i wa al-ra'iyyah) dari perspektif Pemikiran Islam dan berdasarkan pemerhatian kepada Taj al-Salatin.

\section{B. Metode}

Kajian ini merupakan pembahasan literatur (literature review) atas buku Taj alSalatin. Taj al-Salatin ${ }^{4}$ (Mahkota Raja-raja) merupakan sebuah kitab genre ketatanegaraan pertama dalam kesusasteraan Melayu Islam, berbicara persoalan etika kepemimpinan, politik dan pengurusan pemerintahan; mengandungi petunjuk dan panduan dalam menjalankan pemerintahan dan kepimpinan rakyat yang majmuk dari segi etnik, agama dan latar belakang kebudayaan; mengandungi pokok dan dasar pembahasan mengenai kepimpinan yang sangat relevan bagi dunia Melayu Islam di rantau ini pada zaman tersebut dan bahkan sehingga kini. Kitab ini turut berbicara tentang tendensi atau kecenderungan insan untuk melakukan kejahatan yang dilihat jauh lebih kuat berbanding untuk melakukan kebaikan. Justeru, atas alasan ini dikatakan keadilan perlu ditegakkan dengan sebenar-benarnya. Kepentingan kitab ini dapat dilihat dengan jelas terutama dilihat dari segi penerbitan dan percetakannya, sejak abad ke-11/17-13/19, sehingga diulangsalin, diulangterbit dalam pelbagai versi dan diulangterjemah ke dalam pelbagai bahasa besar dunia.

\footnotetext{
${ }^{4}$ Karya Taj al-Salatin ditransliterasikan oleh Khalid M. Hussain, diterbitkan untuk cetakan pertama oleh DBP pada tahun 1966; diindonesiakan oleh Jumsari Jusuf di Indonesia oleh P\&K (Jakarta) pada tahun 1979.
} 


\section{Hasil dan Pembahasan}

\section{Bukhari al-Jauhari dan Tajal-Salatin}

Dari segi ketokohan, walaupun biodatanya sehingga kini masih belum lengkap dan masih suatu misteri, namun secara umumnya dapatlah dikatakan bahawa beliau, dilihat kepada sumbangannya dalam bidang ilmiah, intelektual dan pemikiran kelihatan merupakan seorang pujangga, ulama dan sasterawan Melayu, yang hidup dalam kurun ke-11/17. Besar kemungkinan, beliau juga merupakan seseorang ternama dari kalangan pegawai istana di Aceh dan mempunyai hubungan yang erat dengan Sultan Aceh juga.

Bukhari, nama diberi dan dikaitkan dengan kalimah $J-H-R$, yang membolehkannya menjadi al-Jauhari ataupun al-Johori. Justeru, tidaklah aneh apabila beliau dikatakan berasal dari Johor, ${ }^{5}$ suatu kuasa yang juga berpengaruh besar pada masa tersebut di Alam Melayu. Beliau menetap di Aceh pada zaman pemerintahan Sultan Iskandar Muda Mahkota Alam sehingga terhasil karya besar ini. ${ }^{6}$

Beliau merupakan pengarang kitab Taj al-Salatin yang selesai ditulis pada tahun 1011/1603, dikatakan bersumberkan kepada lebih daripada 50 buah kitab dalam tradisi kesusasteraan Arab dan Parsi. ${ }^{7}$ Taj al-Salatin, karangan beliau bermatlamat menjadi panduan pemerintah kesultanan Melayu Aceh, Sultan Alauddin Riayat Shah (Syah Alam) [yang memerintah 1586-1606].

\footnotetext{
5 Sila lihat Brakel, L.F (1970), "Persian Influence on Malay Literature", Abr-Nabrain, Journal no.9, University of Melbourne, h.1-15.

${ }^{6}$ Lihat pengenalan oleh Muhammad Haji Salleh dalam karya tersebut yang membahaskan ketokohan dan biografi pengarangnya. (Yayasan Warisan Johor, Taj al-Salatin, Johor Baharu: Yayasan Warisan Johor, h.8-9.)

${ }^{7}$ Raja Hisyamuddin Raja Sulong (2014), Pemikiran Politik Raja Ali Haji: Kajian Terhadap Muqaddimab Fi Intizam dan Thamarat al-Mubimmah, (Tesis PhD belum diterbitkan), Jabatan Siasah Syar'iyyah, API, UM, h.48-50.
} 


\section{ARTIKEL}

E-ISSN: $2615-5028$

Sebagai pengarang juga, tidak syak lagi bahawa beliau merupakan penyumbang kepada genre ketatanegaraan yang membolehkan peraturan dalam pemerintahan dan kepimpinan yang digunapakai pada zaman dahulu, tugas dan tanggungjawab semua pihak yang mendiami sesebuah negeri dapat diketahui dengan baik.

\section{Kitab Taj al-Salatin:}

Kitab Taj al-Salatin (TS) atau Mahkota Raja-Raja merupakan genre ketatanegaraan pertama dalam kesusasteraan Melayu-Islam, ${ }^{8}$ berkaitan dengan genre Mirrors of Princes, bersumberkan kepada lebih daripada 50 buah karya dalam kesusasteraan Arab dan Parsi. Ia disebutkan sebagai sumber historiografi tentang sistem pemerintahan kerajaan, dengan kata kuncinya merujuk kepada al-Salatin atau sultan, iaitu suatu terma atau istilah yang kurang popular dalam al-Qur'an dan alHadith tetapi lazim digunapakai dalam konteks dunia Melayu. ${ }^{9}$ Ia mengandungi 24 fasal. Dalam konteks topik dalam artikel ini yang membicarakan hubungan rajarakyat, ia akan terfokus kepada Fasal 20, (Peri segala ra'ayat dengan raja Islam itu) dan Fasal 21 (Peri segala ra'ayat yang kafir dengan raja Islam). ${ }^{10}$

TS sangat masyhur di Alam Melayu, mendapat penilaian tinggi, liputan besar dan meluas serta berpengaruh luas. Besarnya pengaruh TS dapat dilihat daripada kemunculan karya-karya lain yang mendapat sentuhan dan pengaruhnya seperti

\footnotetext{
${ }^{8}$ TS digolongkan dalam genre Penasihatan Khalifah, suatu genre yang telah terkenal di Tanah Arab dalam zaman Umawi dan 'Abbasi dan dipopularkan di Alam Melayu oleh kalangan pegawai istana.

${ }^{9}$ Shah Rul Anuar Nordin (2012), "Pemikiran Politik Islam di Aceh Pada Abad Ke 17M: Kajian Perbandingan Antara Kitab Taj al-Salatin, Sulalah al-Salatin dan Bustan al-Salatin," (Tesis Phd tidak diterbitkan), Fakulti Pengajian Islam, UKM, h.2.

${ }^{10}$ Khalid M.Hussain (2006), Taj Us- Salatin, Kuala Lumpur: DBP, h.ix. 
Safinah al-Hukkam (Aceh), Kitab Nasihat Raja-Raja (Terengganu), Thamarat alMubimmah (Riau) dan Kitab Kumpulan Ringkas Berbetulan Lekas (Riau). ${ }^{11}$

Matlamat dan objektif utama penulisan dan penghasilan karya ini seperti yang dijelaskan oleh pengarangnya: “... menerangkan pada peri perkataan segala raja-raja dan menteri dan hulubalang dan rakyat dan peri kerajaan dan barang yang bergantung pada segala pekerjaan kerajaan itu dengan ibarat yang ihsan dan dengan rajin yang sempurna." ${ }^{12}$ Selain itu, kajian tentang isu-isu kepimpinan dan pemerintahan sezaman juga akan menemukan sebab dan alasan lain yang menyebabkan TS terhasil, di antaranya adalah seperti berikut:

Pertama: Persoalan politik dan kepimpinan merupakan salah satu isu pokok, usul dan fundamental dalam Islam. Ia boleh menaikkan dan bahkan menurunkan dan meruntuhkan individu, masyarakat, bangsa, agama, negara dan bahkan tamadun dunia.

Kedua: Dalam dunia Islam dan hubungannya dengan dunia Melayu-Islam, krisis kepimpinan dan pemerintahan selepas Nabi (s.a.w) agak menonjol dengan meletusnya 3 peperangan saudara (al-Jamal, al-Siffin dan al-Nahrawan), diikuti kepimpinan berasaskan Bani merujuk kepada qabilah dan sya'b seperti Umaiyyah, 'Abbasiyyah dan lain-lain, yang mewujudkan perpecahan dan perebutan kuasa.

Ketiga: Di Alam Melayu umumnya dan di Aceh yang merupakan lokasi terawal kerajaan Muslim Melayu, apatah lagi di istana kesultanan Aceh Dar al-Salam pada akhir-akhir abad ke-10/16 dan awal abad ke-11/17, pergolakan, perpecahan dan perebutan kuasa berlaku sekitar tahun 1575-1604, dan Islam kelihatan tidak berfungsi

${ }^{11}$ Shah Rul Anuar Nordin, op.cit, h.3.

${ }^{12}$ Ibid, (1992), Taj Us-Salatin, Kuala Lumpur: DBP, h.5. 
dengan baik sebagai al-Din atau "a way of life" dalam kehidupan istana. Di sinilah kepentingan dan sumbangan TS kerana ia muncul untuk menawarkan penyelesaian dan penamatan krisis kepimpinan, dan juga mengembalikan kekuatan dan jatidiri Melayu kepada Islam. ${ }^{13}$

\section{Konsep Raja dalam Taj al-Salatin:}

Dalam sistem politik Islam, isu kepimpinan merupakan isu pokok, fundamental, usul dan berpengaruh besar. Keterangan mengenainya terdapat dalam dua sumber utama Islam, al-Qur'an ${ }^{14}$ dan al-Hadith, tetapi ia turut berhadapan dengan kontroversi kerana terdapat pendapat yang menyebutkan "Islam knows no kingship"15 dan juga "al-Nas 'ala din Muluki-bim."16 Dari segi peristilahan atau terminologi, Imam, Khalifah, Uli al-Amr, Wali bahkan Wasi merupakan istilah dan terma yang popular digunapakai. Istilah dan terma lain juga muncul tetapi digunapakai dalam konteks zaman dan isu kontemporari seperti sultan, amir dan lainlain. Untuk tujuan artikel ini, terma yang dipakai adalah al-ra $i$ atau penguasa, pelindung (guardian, keeper, protecter, patron) kerana ia lebih dekat dengan istilah dan terma al-ra'iyah-al-ra'aya atau warga-rakyat. ${ }^{17}$

Pemilihan al-Ra’i dari perspektif Politik Islam terbahagi kepada dua berasaskan dua kategori insan yang dirujuki:

\footnotetext{
13 Abdul Hadi W.M. (2001), Tasawnf yang tertindas, Jakarta: Penerbit Paramadina, h.121-123; Shah Rul Anuar Nordin (2012), "Pemikiran Politik Islam di Aceh..." h.4.

14 'Abd al-Baqi, M.Fuad (1982), al-Mu 'jam al-Mufahras li-Alfaz al-Qur'an al-Karim, Istanbul: al-Maktabah al-Islamiyyah, h.80 (Imam); h.240 (khalifah); h.99 (uli'l-amr); h.354-5 (sultan); h.766-7 (Wali) dll.

${ }^{15}$ Lihat: Muhammad "Aziz Ahmad (1949), Political History and Institutions of the Early Turkish Empire in Delhi, Lahore, h.323; Milner, "Islam and Malay Kingship," dalam Readings on Islam in Southeast Asia, Singapore: ISEAS, h.28.

${ }^{16}$ Muhammad 'Abduh, Syarh Nabj al-Balaghah, Beirut, h.323.

17 Hans Wehr (1961), A Dictionary of Modern Written Arabic, (ed. Cowan, J.M), Wiesbaden: Otto Harrassowitz, h.346
} 
(a) Ma'sum - pilihan Allah, daripada Allah, kepada Allah, untuk Allah.

(b) Ghayr ma'sum - pilihan insan, daripada insan, kepada insan, untuk insan.

Kedudukan Raja (al-Ra’ $)$ penting untuk dilihat kerana ia mempunyai hubungan yang rapat dengan rakyat (al-ra'iyah). Untuk tujuan itu, berikut adalah beberapa tugas dan tanggungjawab Raja ( $\left(\mathrm{ll}-\mathrm{R} \mathrm{a}^{\mathfrak{i} \mathrm{i})}\right.$ dalam sistem politik Islam:

Pertama: Raja (al-Ra’ $)$ sebagai wakil (wafd) dan ketua (qadab) kepada rakyat yang diketuainya, kepada Allah. ${ }^{18}$

Kedua: Raja ( $\left.a l-R a^{\prime} \imath\right)$ sebagai pelindung kepada rakyat (umat manusia).

Ketiga: Raja ( $\left(l-R a^{\prime}\right)$ diwajibkan meletakkan dirinya seperti manusia yang daif $\left(d u^{\prime} a f a\right)$ dari segi makanan, minuman, pakaian agar orang yang faqir boleh mendapat petunjuk dengan kefaqirannya, dan orang yang kaya tidak melampaui batas dalam kekayaannya. ${ }^{19}$ Orang faqir merasa redha terhadap pemberian Allah kepadanya, begitu juga orang-orang kaya merasa bertambah syukur dan tawadu' mereka. ${ }^{20}$

Keempat: Raja (al-Ra’i) sebagai khalifah Allah diharamkan daripada harta Allah kecuali untuk dua bahagian sahaja iaitu untuk makan bagi diri dan keluarga serta untuk memberi makan kepada orang lain. ${ }^{21}$

Kelima: Raja (al-Ra'i) hendaklah melaksanakan perintah Allah dengan menyampaikan nasihat, bersungguh-sungguh menyampaikannya, menghidupkan alsunnah, menegakkan hudud terhadap orang yang berhak menerimanya. ${ }^{22}$

Dari perspektif TS, istilah atau terma Raja, sultan digunapakai. Istilah lain yang turut digunapakai, Zillu'Llah fi'l-ard atau 'ala al-'Alamin. Dalam dunia Islam,

\footnotetext{
18 Al-Majlisi, Bihar al-Anwar, XXIII, h.30; al-Muhammad, Mizan al-Hikmah, I, h.178-179.

${ }^{19}$ Ibn Abi al-Hadid, Syarh Nabj al-Balaghah, XI, h.32

${ }^{20}$ Nahj al-Sa adah, II, h.49.

${ }^{21}$ Ibn Abi al-Hadid, op.cit, XVI, h.204.

22 Ibn Abi al-Hadid, ibid, VII, h.167.
} 
istilah atau terma ini kelihatan dipopularkan dan bahkan dipropagandakan dalam zaman 'Abbasiyyah khususnya berkaitan serangan Mongol ke atas kota Baghdad. ${ }^{23}$

Tentang kedudukan seorang raja dan kerajaannya, Tun Sri Lanang menampilkan kenyataan berikut: "Adalah raja yang adil itu dengan Nabi (saw) umpama dua buah permata pada sebentuk cincin, lagi pun raja itu umpama ganti Allah di dalam dunia, kerana ia zillu'Llah fi'l-alam, apabila berbuat kebaktian kepada raja, seperti berbuat kebaktian kepada Allah SWT yakni berbuat kebaikan kamu akan Allah dan Rasul-Nya dan akan raja..."24

Pemilihan Raja secara umumnya adalah berdasarkan ghayr ma'sum - pilihan insan, daripada insan, kepada insan, untuk insan. Syarat Raja: Umumnya 10 syarat yang dikenalpasti. Pada bahagian akhir fasal 5, Bukhari al-Jauhari mengutip Kitab Adab al-Mulk (karangan Nizam al-Mulk, perdana menteri kepada Alb Arslan, dinasti Saljuq dalam zaman Bani 'Abbasiyyah abad ke-5/11) tentang syarat-syarat seorang raja. Seseorang raja atau al-Räi yang baik adalah seorang Uli al-Albab, iaitu orang yang berilmu pengetahuan, menggunakan akal fikiran dengan baik dalam menjalankan pemerintahan. Berhubung dengan syarat menjadi raja, dikemukakan sepuluh syarat:

1) Pertama, dilihat dari segi usia, raja hendaklah akil baligh atau dewasa, dan berpendidikan, agar dia akan dapat membezakan baik dan jahat;

2) Kedua, dilihat dari segi keilmuan dan pendidikan, raja hendaklah memiliki ilmu pengetahuan yang banyak dan mempunyai visi dan wawasan yang luas.

\footnotetext{
${ }^{23}$ Lihat artikel tentang peranan Khwajah Nasir al-Din al-Tusi yang dituduh menjadi penyebab kepada kejatuhan kota Baghdad kepada Mongol, dlm. Jurnal al-Tawhid.

${ }^{24}$ Shellabear, W.G. (ed) (1961), Sejarah Melayu, Singapore: Malayan Publishing House, h.170-171, 186. Lihat: Mohammad Yusoff Hashim (1994-95), "Daulat" Dalam Tradisi Budaya dan Politik Kesultanan Melayu Abad ke-15 dan Awal Abad ke-16: Antara Mitos dan Realiti," dlm. Lurnal Sejarah, Jabatan Sejarah Universiti Malaya, No.3, h.223.
} 


\section{ARTIKEL}

E-ISSN: $2615-5028$

3) Ketiga, seorang raja mesti pandai memilih menteri. Menteri yang dipilih hendaknya pandai dan berilmu pengetahuan, dengan demikian dapat mengerjakan tugas-tugasnya dengan baaik sesuai bidangnya;

4) Keempat, dilihat dari segi rupa paras dan aspek fizikal, raja hendaklah mempunyai rupa paras yang baik supaya semua orang menyukai dan mencintainya. Jika rupanya kurang baik, hendaklah budi pekertinya tinggi;

5) Kelima, dilihat dari segi sifat, raja hendaklah pemurah dan dermawan, sebab pemurah itu sifat bangsawan dan orang berbudi, sedang kikir itu sifat orang musyrik dan murtad;

6) Keenam, dilihat dari segi budi pekerti, raja hendaklah senantiasa ingat kebajikan orang yang pernah membantunya selama dalam kesukaran, dan membalasnya dengan kebajikan pula;

7) Ketujuh, dilihat dari segi sifat keberanian, raja hendaklah raja itu berani menegur jenderal dan panglima perang, jika yang terakhir ini memang menyalahi perintah dan undang-undang;

8) Kedelapan, dilihat dari segi gaya hidup, raja tidak boleh terlalu banyak makan dan tidur, sebab banyak makan dan tidur merupakan sumber bencana;

9) Kesembilan, dilihat dari segi pergaulan, raja hendaklah tidak gemar main perempuan, sebab gemar akan perempuan bukanlah tanda orang berbudi;

10) Kesepuluh, dilihat dari segi jantina, raja hendaklah lelaki, sebab perempuan lebih suka memerintah di belakang layar dan sering menurutkan emosi dibanding pertimbangan akal. Perempuan dapat dijadikan raja apabila tidak 


\section{ARTIKEL}

E-ISSN: $2615-5028$

ada pemimpin lelaki yang patut dirajakan, asal saja dijaga tidak sampai mendatangkan fitnah. ${ }^{25}$

Raja dianggap penguasa yang memikul amanah yang berat untuk mengatur kehidupan dan mengembangkan peradaban insan. Raja juga merupakan pelindung yang melindungi kesejahteraan rakyat dan kerajaan. ${ }^{26}$ Mereka juga pelaku utama dalam sejarah kemanusiaan dan teladan utama bagi rakyatnya.

Contoh [1]: Kepimpinan para nabi dan rasul seperti Musa, Sulaiman, Yusuf dan Muhammad saw. Semua nabi memiliki kekuasaan untuk memerintah kaumnya, menjalani kehidupan sederhana dan tidak terbelenggu oleh materialisme dan kemegahan duniawi, menjalankan kekuasaan untuk tujuan spiritual, dan bukan untuk tujuan material semata-mata.

Contoh [2]: Kepimpinan para sahabat seperti 'Umar ibn al-Khattab, 'Umar ibn 'Abd al-'Aziz, 'Abd al-Rahman al-Umawi (42-662-132-749). Dalam konteks 'Umar ibn al-Khattab, beliau dilihat pemimpin yang melaksanakan hukuman tanpa memandang bulu, bahkan anaknya sendiri turut menerima hukuman. Kepimpinan raja adil lain yang dijadikan contoh teladan adalah 'Umar ibn 'Abd al-'Aziz dan 'Abd al-Rahman, dua orang khalifah daripada Daulah Bani Umayyah (42/662-132/749) yang dikatakan pemimpin yang arif dan dapat mengendalikan hawa nafsu serta melindungi rakyatnya daripada tindakan sewenang-wenang para pejabat negara.

Contoh [3]: Kepimpinan Harun al-Rasyid al-'Abbasi, khalifah daripada Daulah Bani 'Abbasiyah di Baghdad (133/750-656/1258) yang memegang tampuk

\footnotetext{
25 Akbarizan, "Kepimpinan Perempuan dalam Islam dan Melayu," dlm. Jurnal Toleransi: Media Ilmiah Komunikasi Umat Beragama, Vol.4, No.2, 2012, h.177-194.

${ }^{26}$ Liaw Yock Fang (ed.) (1976), Undang-undang Melaka (The Laws of Melaka), The Hague, h.186.
} 


\section{ARTIKEL}

E-ISSN: $2615-5028$

pemerintahan antara akhir abad ke-2/8 hingga awal abad ke-3/9. Tokoh yang sering muncul sebagai tokoh utama dalam Alfa Layla wa Layla (Kisah Seribu Satu Malam), tidak pernah puas menerima informasi daripada para menteri dan pegawainya; sering ke luar istana pada malam hari dengan menyamar untuk mendengar langsung keluhan dan kritik dari rakyatnya terhadap pemerintahannya; juga seorang pencinta ilmu pengetahuan; mendirikan Khizanat al-Hikmah, sebuah lembaga ilmu pengetahuan yang bertugas menerjemahkan kitab-kitab falsafah dan ilmu pengetahuan dari bahasa Yunani, India, Cina dan Persia ke dalam bahasa Arab, berfungsi sebagai penerbit, perpustakaan dan pusat pendidikan; bahkan yang menarik perhatian juga adalah sepertiga penduduk Baghdad dalam kekuasaannya adalah tamatan universitas. ${ }^{27}$

Contoh [4]: Khusrow I Anusyirwan (Raja Parsi memerintah dari 531 hingga 579 atau abad ke-6M - Daulah Sasan), raja non-muslim yang turut diberikan julukan Zillu'Llah fi'l-ard. Walaupun non-muslim, namun kepimpinan nya yang dilihat berteraskan paksi keadilan membolehkannya dikedepankan sebagai contoh.

\section{Kedudukan Rakyat dalam Taj al-Salatin}

Dalam konteks rakyat terhadap Raja (al-Ra'i), dalam pandangan Islam dikatakan rakyat (al-ra'iyah) mempunyai kewajipan dan tanggungjawab terhadap mereka. Di antaranya adalah seperti berikut:

Pertama: Setiap rakyat [al-ra'iyah] hendaklah mengenali dan mengetahui al-Ra'i (Raja)-nya kerana Nabi (s.'a.w) dikatakan menjelaskan orang yang mati tetapi tidak

27 Abdul Hadi W. M. (2000), Islam: Cakrawala Estetik dan Budaya. Jakarta: Pustaka Firdaus, h.203-5. 
mengetahui al-Ra’i atau Raja zamannya adalah mati dalam keadaan jahiliah yang merujuk kepada pengertian kufr, nifaq dan dalal. ${ }^{28}$

Kedua: Setiap rakyat [al-ra'iyah] diwajibkan mengikuti Raja (al-Ra'i) dari segi hukum-hakam dan sebagainya, dengan kata-kata lain, mereka bertindak sebagai ma'mun. $^{29}$

Ketiga: Setiap rakyat [al-ra'iyah] dikehendaki merujuk kepada Raja (al-Ra' $)$ dalam segala persoalan dan perselisihan di antara mereka. ${ }^{30}$

Keempat: Setiap rakyat [al-ra'iyah] dikehendaki menjadikan Raja (al-Ra'i) sebagai Wali (awliya) dan menjadikan musuh-musuhnya sebagai musuh-musuh mereka dan tidak bersekongkol, bersubahat dan membantu mereka. ${ }^{31}$

Kelima: Setiap rakyat dikehendaki menyintai $a l-R a^{\prime} t$.

Keenam: Setiap rakyat [mukallaf] dikehendaki mentaati Raja (al-Ra`), wasi (awsiya) yang baik seperti disebutkan dalam al-Qur'an ${ }^{32}$ dan tidak diwajibkan mentaati al-Ra’i atau Raja yang tidak mentaati Allah ${ }^{33}$ kerana ketaatan hanya diwajibkan Allah, Rasul dan Wulat al-Amr. ${ }^{34}$ Begitu juga manusia tidak boleh mentaati al-Ra'i atau Raja yang mempunyai sifat takabbur, ta'sub, pencetus fitnah dan ciri-ciri jahiliah. ${ }^{35}$

Ketujuh: Setiap rakyat [mukallaf] dikehendaki keluar (berjihad) menentang Raja (al-Ra’’) yang zalim (al-jaur) kerana kematian dalam mentaati Allah adalah lebih

\footnotetext{
28 Al-Hurr al- 'Amili, al-Fusul al-Mubimmah, h.141.

${ }^{29}$ Muhammad Taqi, Sabifah al-Abrar, I, h.271.

${ }^{30}$ Al-Hurr al-`Amili, op.cit, h.149.

${ }^{31}$ Lihat: Al-Qur'an, surah al-Mujadalah (58): 22.

32 Lihat: Al-Qur'an, surah al-Nisa' (4): 59 dan surah al-Ma'idah (5): 55.

33 Al-Muhammadi, Mizan al-Hikmah, I, h.183.

34 Al-Muhammad, ibid, I, h.183.

35 Ibn Abi al-Hadid, Syarh Nahj al-Balaghah, XIII, h.146; Lihat: Al-Qur'an, surah al-Ahzab (33): 67.
} 


\section{ARTIKEL}

baik daripada kehidupan dalam mengingkari Allah. ${ }^{36}$ Di samping itu, orang-orang yang bodoh dan jahat tidak boleh dibiarkan melakukan keburukan dan kejahatan. ${ }^{37}$

Dalam pembicaraan TS berhubung dengan rakyat, fokusnya adalah kepada Fasal 20 dan Fasal 21. ${ }^{38}$ Dikemukakan 20 hak rakyat Muslim terhadap raja mereka yang Muslim, dan berikut adalah senarai hak tersebut:

Pertama: Rakyat Muslim dalam konteks ketaatan, hendaklah mentaati raja yang merendahkan diri dan merendahkan hati, atau dengan kata-kata lain, tidak membesarkan diri (mutakabbir). ${ }^{39}$

Kedua: Rakyat Muslim dalam konteks suara dan hak bersuara, hendaklah memperdengarkan suara mereka keseluruhannya, dan raja pula dikehendaki tidak hanya kepada sebahagian dan melupakan sebahagian yang lain. ${ }^{40}$

Ketiga: Rakyat Muslim dalam konteks hukuman, hendaklah seboleh mungkin mereka diampuni dan tidak dimurkai bahkan sekiranya mampu, hendaklah diampuni mereka dalam jangka masa yang ditetapkan. ${ }^{41}$ Keempat: Rakyat Muslim dalam konteks kasih sayang, hendaklah dipelihara dan dibelaskasihani tanpa mengira sama ada mereka terdiri daripada orang mu'min, kafir, fasiq, saleh, jahat dan lain-lain. ${ }^{42}$

Kelima: Rakyat Muslim dalam konteks tuan rumah, hendaklah diberikan hak tuan rumah, dijaga dan dipertahankan hak mereka dan tidak dibenarkan masuk ke dalam rumah tanpa izin.

\footnotetext{
${ }^{36}$ Al-Muhammadi, ibid, I, h.185; Nabj al-Sa adah, II, h.639.

${ }^{37}$ Ibn Abi al-Hadid, op.cit, VI, h.99.

${ }^{38}$ Raja Hisyamuddin Raja Sulong (2014), Pemikiran Politik Raja Ali Haji..., h.102-104.

${ }^{39}$ Khalid Hussain, Taj al-Salatin, h.192.

${ }^{40} \mathrm{Ibid}, \mathrm{h} .193$.

${ }^{41}$ Ibid, h.194.

42 Ibid, h.195.
} 
Keenam: Rakyat Muslim dari segi kedudukan, hendaklah dihormati pangkat dan kedudukan mereka sama ada mereka orang 'alim dan fadhil atau abmaq dan tidak berbudi bahasa. Setiap mereka hendaklah diberikan hak sebagaimana yang sewajarnya. $^{43}$

Ketujuh: Rakyat Muslim khususnya yang tua hendaklah dihormati atau diberikan penghormatan yang selayaknya sekalipun mereka ilmuan yang salih, 'abid dan zahid mahupun seorang yang jahil. ${ }^{44}$

Kelapan: Rakyat Muslim dalam konteks janji, hendaklah ditunaikan, dipenuhi dan disempurnakan janji itu. ${ }^{45}$

Kesembilan: Rakyat Muslim dalam konteks hukuman yang dijatuhi, hendaklah dihukum dalam keadaan raja bermuka baik, dan dalam keadaan kata-kata yang juga baik dan lemah lembut. ${ }^{46}$

Kesepuluh: Rakyat Muslim dalam konteks keadilan dalam hukuman, hendaklah dijatuhi hukuman dengan adil dan insaf. ${ }^{47}$

Kesebelas: Rakyat Muslim dalam konteks perselisihan dan pertelagahan, hendaklah cuba didamaikan di antara kedua-dua belah pihak yang bertelagah. ${ }^{48}$

Keduabelas: Rakyat Muslim dalam konteks kesalahan yang dilakukan, hendaklah diberikan pengadilan, dan tidak dibenarkan mengaibkan mereka. ${ }^{49}$

Ketigabelas: Rakyat Muslim dalam konteks perbuatan salah, hendaklah cuba disembunyikan dan tidak didedahkan kepada khalayak umum. ${ }^{50}$

\footnotetext{
${ }^{43}$ Ibid, h.196.

${ }^{44}$ Ibid, h.196.

${ }^{45}$ Ibid, h.197.

46 Ibid, h.197.

${ }^{47}$ Ibid, h.197-8.

48 Ibid, h.198.

${ }^{49}$ Ibid, h.198-9.
} 


\section{ARTIKEL}

E-ISSN: $2615-5028$

Keempatbelas: Rakyat Muslim dalam konteks pekerjaan yang sukar, hendaklah cuba dipermudahkan pekerjaan atau perbuatan itu. ${ }^{51}$

Kelimabelas: Rakyat Muslim dalam konteks kefaqiran dan kemiskinan, hendaklah dihormati dan dimuliakan melebihi orang kaya. ${ }^{52}$

Keenambelas: Rakyat Muslim dalam konteks kefaqiran dan kemiskinan, hendaklah dibantu, tidak dialpakan akan faqir, miskin, yatim dan dhaif, dan bahkan sentiasa ingat akan mati. ${ }^{53}$

Ketujuhbelas: Rakyat Muslim dalam konteks keselamatan dan ketenteraman awam, hendaklah dilindungi daripada kejahatan orang jahat. ${ }^{54}$

Kelapanbelas: Rakyat Muslim dalam konteks kemudahan perhubungan, hendaklah dibina tempat perhentian dan jambatan untuk perhubungan mereka. ${ }^{55}$

Kesembilanbelas: Rakyat Muslim dalam konteks mengimarahkan masjid, hendaklah disediakan bantuan kewangan untuk masjid, khatib dan muazzin. ${ }^{56}$

Keduapuluh: Rakyat Muslim dalam konteks amar ma'ruf naby munkar, hendaklah dianjurkan berbuat kebaikan dan dihindari dan dijauhi berbuat kejahatan, dan hukuman yang sewajarnya perlu disediakan. ${ }^{57}$

Dalam konteks rakyat yang kafir terhadap raja Muslim pula, hubungan rajarakyat adalah digambarkan berdasarkan peristiwa pada zaman 'Umar ibn al-Khattab terutama dengan kemasukan orang kafir dalam negara Muslimin dari segi

\footnotetext{
${ }^{50} \mathrm{Ibid}$, h. 200 .

${ }^{51}$ Ibid, h.200.

${ }^{52} \mathrm{Ibid}, \mathrm{h} .201$.

${ }^{53}$ Ibid, h.201-2.

${ }^{54}$ Ibid, h.202.

${ }^{55} \mathrm{Ibid}, \mathrm{h} .203$.

${ }^{56}$ Ibid, h.203.

${ }^{57}$ Ibid, h. 204.
} 


\section{ARTIKEL}

pemeteraian kerjasama dan ikatan setia. ${ }^{58}$ Dalam TS, terdapat keterangan yang jelas dengan ditetapkan 20 syarat dalam konteks hubungan di antara rakyat kafir-raja Muslim ${ }^{59}$ seperti berikut:

Syarat pertama dan kedua: Rakyat kafir dalam konteks keberagamaan, hendaklah tidak dibenarkan membuat berhala dan segala tanda kekufuran mereka; manakala mereka, selepas berada dalam naungan, pemeliharaan dan perlindungan raja Muslim, tidak dibenarkan membina kembali berhala yang telah rosak.

Syarat ketiga, keempat dan kelima: Rakyat Muslim yang berniaga dan berkunjung ke negeri kafir, tidak harus menghormati berhala mereka; dan sekiranya mereka berhenti di rumah orang kafir, hendaklah tidak lebih dari 3 hari; dan seterusnya, rakyat kafir tidak boleh diberikan tempat dalam rumah dan kampung. ${ }^{60}$

Syarat keenam, ketujuh, kelapan: Rakyat kafir yang ingin memeluk Islam, hendaklah tidak dilarang untuk berbuat demikian; dan mereka dikehendaki menghormati dan memberikan hormat kepada rakyat muslim; dan sekiranya dalam sesuatu perhimpunan yang dihadiri rakyat muslim, mereka (rakyat Muslim) hendaklah diberi penghormatan.

Syarat kesembilan, kesepuluh: Rakyat kafir tidak dibenarkan memakai pakaian Muslim ataupun menyerupai mereka; dan mereka pula tidak dibenarkan menaiki atau menunggang kuda berpelana.

Syarat kesebelas, keduabelas: Rakyat kafir tidak dibenarkan memiliki senjata untuk diri dan dalam rumah mereka; dan mereka tidak pula dibenarkan memakai cincin permata atau cincin berlambang Islam.

\footnotetext{
${ }^{58}$ Raja Hisyamuddin Raja Sulong (2014), Pemikiran Politik Raja Ali Haji..., h.104-112.

${ }^{59}$ Op.cit, h.205.

${ }^{60}$ Ibid, h.206.
} 


\section{ARTIKEL}

Syarat ketigabelas: Rakyat kafir tidak dibenarkan menjual beli khamar, tuak; dan mereka juga tidak diharuskan meminumnya di hadapan rakyat Muslim.

Syarat keempatbelas, kelimabelas: Rakyat kafir dengan barang resam dan adat hendaklah diketepikan; dan perbuatan kufur mereka tidak boleh dinyatakan kepada Muslim lain.

Syarat keenambelas - duapuluh: Rakyat kafir tidak dibenarkan menamakan anak cucu mereka dengan nama muslim. Rumah mereka tidak dibenarkan dibina berdekatan rumah muslim. Mereka tidak dibenarkan dikebumikan atau dibakar dekat dengan perkuburan muslim. Kematian mereka tidak harus ditangisi dan diratapi. Rakyat kafir tidak dibenarkan memeras muslim.

\section{Analisis Perbandingan}

Secara perbandingan dalam Siyasah Islamiyyah (SI) dan Taj al-Salatin (TS) memperlihatkan bahawa:

Dalam konsep kepimpinan; SI berbicara tentang 2 bentuk kepimpinan, ma'sum dan ghayr ma'sum; sistem teokrasi (pilihan raja segala raja dan raja seluruh alam atau Allah), dalam bahasa yang lebih mudah, "daripada Allah, kepada Allah dan untuk Allah,"; TS pula berbicara tentang suatu bentuk kepimpinan ghayr ma'sum, sistem demokrasi (pilihan rakyat dunia Melayu), dengan kata-kata lain, "daripada rakyat, kepada rakyat dan untuk rakyat."

Dalam persoalan sumber kepimpinan; SI bersumberkan al-Qur'an, al-Hadith dan aplikasi kedua-duanya secara tekstual dan kontekstual, terutama wawasan dan gagasan Nabi Muhammad (s.aw) yang dapat diobservasi, diperhati, dihayati dan diimplementasi secara vertikal mahupun horizontal; manakala TS pula bersumberkan al-Qur'an, al-Hadith, teorikal, praktikal, realiti semasa dalam konteks zaman dan 


\section{ARTIKEL}

keadaan, sama ada berdasarkan sumber muslim mahupun non-muslim, yang dilihat memenuhi syarat dan kriterianya.

Dalam konteks pemilihan kepimpinan; SI melibatkan dua perspektif pemilihan, Allah dan insan; manakala TS pula hanya melibatkan satu perspektif sahaja, insan, selain ia juga boleh termasuk non-Islamik dan non-muslim juga.

Dalam konteks matlamat kepimpinan; SI bermatlamat untuk kembalikan seluruh sistem, proses dan pencapaian pelaksanaannya kepada pemilik dan punca kuasa Maha Besar, Allah SWT; manakala TS pula bermatlamat untuk kembalikan keseluruhannya kepada raja (al-rå), kerajaan (al-ri 'ayah) dan pada akhirnya kepada Allah SWT.

Dalam konteks hubungan raja-rakyat (al-ra'i wa al-ra'iyab), dapatlah dikatakan bahawa SI dan TS mempunyai persamaan dari segi visi, misi, objektif dan matlamatnya. Perbezaannya tetap wujud sekiranya analisis perbandingan dilakukan secara seimbang dan berimbang seperti berikut:

1) Pada asasnya, Raja merupakan penaung, penjaga, pelindung dan pemimpin manakala rakyat pula yang dinaungi, dijagai, dilindungi dan dipimpin. Hak dan tanggungjawab yang lebih besar diserahkan kepada pemegang kuasa untuk menggunakan kuasa untuk menguasai rakyat dengan sebaik dan seadilnya. Apatah lagi, dalam konteks TS, penekanan begitu besar diberikan kepada aspek keadilan sehingga ia boleh dilihat sebagai teras dan tunjang raja dan kerajaannya.

2) Raja merupakan bayangan Tuhan di muka bumi, manakala rakyat pula diteduhi dan dipayungi bayangan tersebut. 
3) Raja-rakyat muslim dalam konteks ketaatan begitu ketara mengikat satu dengan yang lain. "Raja ditaati-rakyat mentaati" berpaksikan kepada konsep keadilan.

4) Raja-rakyat muslim dalam konteks hak bersuara, hukuman, penyelesaian masalah dan lain-lain, rakyat diberikan ruang dan peluang untuk terlibat dan dijaga hak mereka, dan menjadi tanggungjawab raja untuk mendengar suara rakyat keseluruhannya.

5) Dalam konteks Raja-rakyat kafir pula, terdapat perbincangan yang jelas dalam SI dan TS. Ia memperlihatkan Islam bertindak sebagai sistem dan polisi yang mendasari seluruh pemerintahan, dan rakyat kafir diberikan hak tertakluk kepada sistem Islam yang dikuatkuasakan. Dengan kata-kata lain, apa yang dibenarkan Islam, dibenarkan kepada rakyat kafir, sebaliknya apa yang ditegah Islam, ditegah kepada rakyat kafir.

\section{Kesimpulan}

Bukhari al-Jauhari, suatu nama yang besar tetapi penuh misteri; merupakan tokoh pemikir politik, ulama, sasterawan Melayu yang tidak dikenalpasti dengan baik kerana kekurangan maklumat tentang biodatanya. Walaupun tidak lengkap, namun kajian dan analisis masih boleh dilakukan terhadapnya menerusi hasil usaha dan sumbangan ilmiah dan intelektualnya kepada dunia Melayu dan dunia Islam umumnya. Seperkara yang menarik juga apabila Bukhari al-Jauhari dilihat berkemungkinan besar seorang penganut mazhab al-Maturidiyyah dalam bidang Usulu'd-Din (teologi) dan mazhab al-Hanafiyyah dalam bidang fiqh. 


\section{ARTIKEL}

E-ISSN: $2615-5028$

Kitab Taj al-Salatin merupakan kitab berkaitan politik dan ketatanegaraan yang pertama ditemui di Alam Melayu, dengan impaknya cukup meluas, pengaruhnya begitu besar dan menarik perhatian para pengkaji dalam dan luar. Ia kelihatan suatu kitab yang tidak dapat tidak, pasti dirujuk untuk memahami teori politik MelayuIslam dalam konteks Nusantara. Konsep Raja-Rakyat dalam Pemikiran Politik Melayu dan Imam-Ummah dalam Pemikiran Politik Islam mempunyai kaitan yang rapat kerana isu politik kepimpinan merupakan isu pokok yang bersifat fitrah. Perbincangan tentang Raja-Rakyat dalam TS kelihatan mencampuradukkan teori dan realiti politik semasa dalam setiap zaman sebagai acuan Teori Politik Islam, dengan kepimpinan semasa seperti Raja Khusrow I Anushirwan dan lain-lain dikemukakan tetapi ia pada hakikatnya bukanlah yang terbaik dari pandangan Islam. Ia tidaklah sebenarnya menggambarkan sistem politik Islam beracuankan kalam Allah, al-Qur'an, qaul dan fi'l Nabi Muhammad saw dalam sepanjang kepimpinan baginda saw, bahkan anbiya' dan mursalin sebelum baginda saw. Kepimpinan Nabi saw yang terpelihara daripada dosa dan salah (ma'sum) tidak diberikan penekanan yang besar dan mendalam. Walhal Nabi saw sendiri telah mewujudkan kerajaan Islam Madinah menerusi piagam atau Dustur Madinah yang wajar dikembangkan, dipertahankan dan dicontohi sepanjang zaman. Konsep Rakyat atau al-ra'iyah dalam Pemikiran Politik Melayu dan Ummah dalam Pemikiran Politik Islam pada dasarnya hampir sama, kerana Melayu merupakan salah sebuah bangsa yang tertakluk dalam pengertian ummah, tetapi agak berbeza dalam konteks Islam yang lebih syumul, tanpa perbezaan bangsa bahkan semua bangsa tertakluk di dalamnya. Dalam konteks hubungan Rajarakyat, al-Ra'i wa al-ra'iyah atau al-Imam wa al-ummah dari persektif Melayu dan Islam bersifat universal dan fitrah. Namun, perbezaannya tetap wujud kerana perspektif 
Islam jauh lebih meluas dan melebar tanpa batasan dan had. Kepentingan, relevansi dan signifikan kitab Taj al-Salatin kepada peradaban dan tamadun Melayu memang ketara dan tidak dapat disangkal sama sekali. Ia beracuan dan mendapatkan pengaruh dari Islam.

\section{DAFTAR PUSTAKA}

'Abd al-Baqi, M.Fuad. al-Mu'jam al-Mufahras li-Alfaz, al-Qur'an al-Karim, Istanbul: alMaktabah al-Islamiyyah, 1982.

'Abduh, Muhammad. Syarb Nahj al-Balaghah, (2 vol.), Dar al-Andalus, Beirut, 1382/1963.

Abdul Hadi W.M. Islam: Cakrawala Estetik dan Budaya, Jakarta: Pustaka Firdaus, 2000.

Ahmad, Muhammad 'Aziz. Political History and Institutions of the Early Turkish Empire in Delhi, Lahore, 1949.

Akbarizan, "Kepimpinan Perempuan dalam Islam dan Melayu," dlm. Jurnal Toleransi: Media Ilmiah Komunikasi Umat Beragama, Vol.4, No.2, 2012.

Al-Hurr al-'Amili, Muhammad bin al-Hasan. al-Fusul al-Mubimmah, al-Maktabah wa al-Matba'ah al-Haydariyyah, al-Najaf, Cet.II. 1378/1958.

Ali, WZ Kamaruddin Wan. Asal-Usul, Pengaruh dan Kesan Aliran Al-Asy'ari dan alAsy'ariyyah di Malaysia dan Kepulauan Melayu, Kuala Lumpur: Persatuan Sejarah Malaysia, 1994.

Al-Syahrastani. al-Milal wa al-Nihal, Tahqiq: 'Abd al-'Aziz Muhammad al-Waki', (3 vol.), al-Qahirah: Mu'assasah al-Halabi, 1380/1961. 


\section{ARTIKEL}

Al-Syahri, Al-Muhammadi al-Riyy. Mizan al-Hikmah (10 vol.), Maktab al-A'lam alIslami, Qum, 1984.

Awang, Omar. "The Major Arabic Sources Which Determined the Structure of Islamic Thought in the Malay Archipelago Before the Nineteenth Century A.H in the Field of Law, Theology and Sufism," dlm. Islamika, Cet.I, Kuala Lumpur.

Brakel, L.F "Persian Influence on Malay Literature", Abr-Nahrain, Journal no.9, University of Melbourne, 1970.

Browne, Edward G.A. A Literary History of Persia, 4 vols., Cambridge: Cambridge University Press, 1976.

Hashim, Mohammad Yusoff. "Daulat" Dalam Tradisi Budaya dan Politik Kesultanan Melayu Abad ke-15 dan Awal Abad ke-16: Antara Mitos dan Realiti," dalam Jurnal Sejarah, Jabatan Sejarah Universiti Malaya, No.3 (1994).

Ibn Abi al-Hadid. Syarh Nabj al-Balaghah, Tahqiq: Muhammad Abu al-Fadl Ibrahim, Dar Ihya’ al-Turath al-'Arabi, Beirut, 1385/1965.

Khalid Hussain. Taj Us-Salatin. Kuala Lumpur: Dewan Bahasa dan Pustaka, 1966.

Liaw Yock Fang (ed.) Undang-undang Melaka (The Laws of Melaka), The Hague, 1976.

Milner, A.C. "Islam and Malay Kingship," dalam Readings on Islam in Southeast Asia, Singapore: ISEAS, 1985.

Ngah, Mohd Nor. Kitab Jawi: Islamic Thought of The Malay Muslim Scholars, Singapore: ISEAS, 1983. 
Nordin, Shahrul Anuar. Pemikiran Politik Islam di Aceh pada Abad ke-17M: Kajian Perbandingan antara Kitab Taj al-Salatin, Sulalah al-Salatin dan Bustan al-Salatin, (tesis PhD belum diterbitkan), Bangi: Fakulti Pengajian Islam, UKM, 2012.

Rahman, M. Taufiq. Glosari Teori Sosial. Bandung: Ibnu Sina Press. 2011.

Sulong, Raja Hisyamuddin Raja. Pemikiran Politik Raja Ali Haji: Kajian Terbadap Muqaddimah Fi Intizam dan Thamarat al-Mubimmah, (Tesis $\mathrm{PhD}$ belum diterbitkan), Jabatan Siasah Syar'iyyah, Akademi Pengajian Islam, UM, KL, 2014.

Taqi, Muhammad. Sahifah al-Abrar, Tahqiq: Hujjah al-Islam 'Abd al-Rasul al-Haqa'iqi al-Ha’iri, (2 vol.), Dar al-Jayl, Beirut, 1993.

Wehr, Hans. A Dictionary of Modern Written Arabic, (ed.Cowan, J.M), Wiesbaden: Otto Harrassowitz, 1961.

Yayasan Warisan Johor. Taj al-Salatin (Mabkota Raja-raja), Johor Baharu: Yayasan Warisan Johor, 2001. 